\title{
Pengaruh E-service Quality Terhadap Keputusan Pengguna Jasa Ojek Online Go-Ride dalam Aplikasi Go-Jek melalui Kepercayaan Konsumen di Kota Jambi
}

\author{
Mohammad Ihsan, Ade Perdana Siregar \\ Program Studi Manajemen Fakultas Ekonomi dan Bisnis Universitas Jambi \\ Correspondence email: ade.perdana@unja.ac.id
}

\begin{abstract}
The purpose of this study was to identify the effect of e-service quality on consumer trust in Go-Ride online motorcycle taxi users in the Go-Jek application in Jambi City. identify the influence between e-service quality and consumer trust in the decisions of Go-Ride online motorcycle taxi users in the Go-Jek application in Jambi City and identify the influence of e-service quality on Go-Ride motorcycle taxi users' decisions on the Go-Jek application through consumer trust in Jambi City. The population of this study was the people of Jambi city while the sample was the people of Jambi city who more than once used the Go-Jek service as many as 150 people. The data method uses path analysis. The results of the study revealed that e-service quality had a significant influence on consumer trust in Go-Ride online motorcycle taxi users in the Go-Jek application in Jambi City, e-service quality and consumer trust had a significant influence on Go-ojek online motorcycle users' decisions. Ride on the Go-Jek application in Jambi City and e-service quality had a significant influence on consumer trust in Go-Ride online motorcycle taxi users in the Go-Jek application through consumer trust in Jambi City
\end{abstract}

Keywords: E-service Quality, Consumer Trust, Service User Decision

\section{PENDAHULUAN}

Pada era globalisasi persaingan bisnis yang dihadapi perusahaan-perusahaan saat ini semakin ketat, bisnis jasa saat ini semakin beragam dalam rangka memenuhi kebutuhan hidup masyarakat. Masyarakat mempunyai aktivitas yang beragam dan memerlukan adanya transportasi sebagai alat penunjang atau alat bantu dalam melakukan aktivitasnya. Pengusaha jasa transportasi berlomba-lomba menggaet konsumennya dengan peningkatan pelayanan, kemudahan pemesanan, kenyamanan armada, ketepatan waktu dan lain sebagainya. Di Indonesia khususnya di Kota Jambi banyak dijumpai sepeda motor melakukan fungsi sebagai kendaraan umum yaitu mengangkut orang atau barang dan memungut biaya yang disepakati, model transportasi jenis ini dikenal dengan nama ojek. Sebelumnya ojek memakai sistem pangkalan berbasis wilayah di tikungan dan mulut-mulut gang. Pengendaran ojek dari wilayah lain tidak bisa sembarangan "mangkal" di suatu wilayah tanpa ijin dari pengendara ojek di wilayah tersebut. Dalam mengggunakan jasa ojek, pemakai jasa harus membayar kontan dan tidak jarang sering ditawari tawar-menawar. Seiring berjalannya waktu, di era globalisasi perkembangan teknologi mengambil peranan yang sangat penting karena mempermudah manusia dalam melakukan berbagai aktivitas kehidupan. Para pengusaha harus membuat inovasi baru yaitu memberikan kemudahan kepada pelanggan dalam melakukan transaksi sehingga mempertahankan pangsa pasar untuk tetap meningkat dengan memanfaatkan media internet di perkembangan teknologi, dan salah satunya adalah layanan elektronik atau $e$-service.

Menurut Rowley (2006) layanan elektronik di definisikan sebagai: "... perbuatan, usaha atau pertunjukan yang pengiriman di mediasi oleh teknologi informasi. Definisi ini mencerminkan tiga komponen utama penyedia layanan, penerima layanan dan saluran pelayanan yaitu, teknologi. Kassim \& Abdullah (2010) mengidentifikasi lima dimensi service quality yang terkait dengan harapan pelanggan yaitu: reliability (kehandalan), assurance (jaminan), tangibles (tampilan fisik), emphaty (empati), dan responsiveness (daya tanggap). Dimensi e-service quality dilihat dari dua perspektif, yaitu perspektif perusahaan dan perspektif pelanggan. Jika dilihat dari perspektif perusahaan, maka dimensi e-service yang harus diperhatikan adalah ease of use (kemudahan bagi pelanggan untuk menggunakan website), website design (website harus didesain dengan baik dan menarik secara visual), reliability (konsistensi kinerja dan kehandalan web), system availability (fungsi teknis yang benar dari website), privacy (keamanan dan perlindungan informasi pelanggan), responsiveness (penanganan masalah dan pengembalian yang efektif melalui internet), dan empathy (perawatan dan perhatian individual yang diberikan kepada pelanggan 
melalui saluran elektronik). Sedangkan jika dilihat dari perspektif pelanggan, maka dimensi e-service yang harus diperhatikan adalah experience (kesan mengenai perusahaan melalui pelanggan terdahulu) dan trust (kepercayaan pelanggan dengan memberikan pelayanan yang cepat dan kaya informasi). Kualitas pelayanan dan kepercayaan konsumen adalah faktor keberhasilan dari suatu perusahaan untuk mencapai keunggulan bersaing. Dilihat dari kualitas layanan yang terbaik dapat menciptakan kepercayaan konsumen dan keputusan konsumen dalam menggunakan jasa. (Adisetiawan, 2013)

Kepercayaan merupakan sesuatu yang timbul ketika salah satu kelompok yakin atau percaya dengan reabilitas atau keandalan dan integritas exchange partnernya. Kepercayaan digunakan untuk menggambarkan perasaan, keyakinan, perilaku, dan persepsi. Terdapat beberapa faktor yang dapat menumbuhkan kepercayaan kosumen yaitu reputasi, keamanan bertransaksi dan keandalan sistem. Winardi (2010) menyatakan keputusan pembelian atau menggunakan jasa merupakan titik suatu pembelian atau pengguna jasa dari proses evaluasi. Proses evaluasi konsumen dalam menentukan keputusan menggunakan jasa tentunya dengan pertimbangan kualitas yang dirasakan oleh konsumen melalui kepercayaan konsumen terhadap layanan tersebut. Di Jambi saat ini tersedia penyedia jasa transportasi ojek online yang tidak memiliki aturan tertentu, baik secara standar pelayanan, jam operasional dan sebagainya, salah satunya bisnis jasa memberikan layanan pesan - antar produk atau jasa tersebut yaitu Go-Jek. Perusahaan ini dirintis sejak tahun 2011 oleh Nadiem Makarim dan rekannya Michael Angelo Moran. Pada awalnya perusahaan ini menjalankan bisnis dengan menggunakan call center yaitu para staf Go-Jek menghubungi satu per satu dari pengendara Go-Jek yang kosong melalui telepon. Dengan menggunakan layanan elektronik yaitu call center membuat staf Go-Jek semakin tidak efesien karena harus menghubungi satu per satu Go-Jek yang kosong dan ini sangat memakan waktu. Sejak diluncurkan pemesanan Go-Jek berbasis aplikasi di android dan ios, bisnis ini mulai berkembang dengan sangat pesat. Aplikasi mobile baru luncur bulan Januari 2015 dan masuk di Kota Jambi pada bulan April 2017, karena dirasa masyarakat sudah siap dengan perangkat androidnya (bukan lagi Blackberry) dan pertumbuhan penggunaan smartphone dan paket data yang ada di Indonesia. Pangsa pasar dari perusahaan Go-Jek sangat besar, untuk itu perusahaan harus dapat mempertahankan pangsa pasar dengan meningkatkan kualitas pelayanan sesuai dengan keinginan pelanggan. Keinginan pelanggan menjadi satu kunci perusahaan untuk tetap eksis, dari sinilah kita dapat membangun dasar dari masukan pelanggan untuk terus berjaya di era globalisasi. Dalam penelitian ini hanya mengambil pada jasa layanan Go Ride karena pada layanan Go Ride pelanggan dapat merasakan layanan mulai dari pemesanan hingga sampai ke tempat tujuan.

Tujuan dalam penelitian ini adalah mengidentifikasi pengaruh antara e-service quality terhadap kepercayaan konsumen pengguna jasa ojek online Go-Ride pada aplikasi Go-Jek di Kota Jambi, mengidentifikasi pengaruh antara e-service quality dan kepercayaan konsumen terhadap keputusan pengguna jasa ojek online Go-Ride pada aplikasi Go-Jek di Kota Jambi dan mengidentifikasi pengaruh antara e-service quality terhadap keputusan pengguna jasa ojek online Go-Ride pada aplikasi Go-Jek melalui kepercayaan konsumen di Kota Jambi. E-commerce adalah tata cara perdagangan barang dan jasa yang menggunakan media telekomunikasi dan telekomunikasi sebagai alat bantunya. E-commerce hanya merupakan bagian dari e-business yang hanya berfokus pada kegiatan transaksi. E-marketing merupakan salah satu bagian dari kegiatan organisasi e-business dimana e-marketing sendiri memiliki definisi sebagai pemanfaatan teknologi informasi dalam sebuah proses pembuatan, pengkomunikasian dan pengiriman value kepada konsumen serta untuk mengelola hubungan terhadap konsumen, dimanna hal tersebut akan memberikan keuntungan bagi organisasi bisnis dan para stakeholders. (Asmas dkk, 2018)

E-service quality sebagai evaluasi konsumen secara keseluruhan serta penilaian terhadap kualitas dari pelayanan pengiriman dalam virtual market place. Rowley (2006) layanan elektronik di definisikan sebagai perbuatan, usaha atau pertunjukan yang pengiriman di mediasi oleh teknologi informasi. Kassim \& Abdullah (2010), indikator yang digunakan untuk menilai e-service quality adalah ease of use, website design, responsiveness dan assurance. Kepercayaan merupakan sesuatu yang timbul ketika salah satu kelompok yakin atau percaya dengan reabilitas atau keandalah dan integritas exchange partnernya. Kepercayaan konsumen didefinisikan sebagai harapan konsumen bahwa penyedia jasa dapat dipercaya atau diandalkan dalam memenuhi janjinya. Indikator-indikator yang digunakan untuk menilai kepercayaan konsumen adalah reputasi, keamanan bertransaksi dan keandalan system. Winardi (2010), keputusan 
pembelian atau menggunakan jasa merupakan titik suatu pembelian atau pengguna jasa dari proses evaluasi. Kotler dan Keller (2009), proses keputusan pembelian konsumen atau menggunakan jasa harus melewati lima tahap yaitu pengenalan masalah, pencarian informasi, evaluasi alternatif, keputusan pembelian dan perilaku pasca pembelian.

\section{METODE PENELITIAN}

Jenis data yang digunakan dalam penelitian ini adalah data Primer yaitu data yang diperoleh langsung melalui pertanyaan yang meliputi : karakteristik responden, persepsi responden tentang $e$-service quality, kepercayaan responden menggunakan jasa pada e-service serta hubungannya dengan keputusan pengguna jasa dan data Sekunder yaitu data yang diperoleh dari tinjauan kepustakaan melalui literature, jurnal-jurnal dan situs internet yang dapat memberikan informasi sesuai dengan masalah penelitian. Populasi pada penelitian ini adalah pelanggan dari GO-jek di Kota Jambi sedangkan sampel dalam penelitian ini adalah pelanggan yang menggunakan layanan GO-jek lebih dari satu kali sebanyak 150 responden.

Teknik pengumpulan data yang digunakan dalam penelitian ini meliputi : metode observasi merupakan pengumpulan data yang dilakukan dengan mengadakan pengamatan langsung agar diperoleh data yang nyata dan metode interview merupakan mendapatkan data dengan melakukan penyebaran kuesioner dan tanya jawab yang berguna untuk melengkapi data yang diperoleh dengan metode sebelumnya. Variabel yang digunakan dalam penelitian ini adalah e-service quality (X) dengan indikator ease of use, website design responsiveness dan assurance, kepercayaan konsumen (Y1) dengan indikator reputasi, keamanan bertransaksi dan keandalan sistem serta keputusan pengguna jasa (Y2) dengan indikator pengenalan masalah, pencarian informasi, evaluasi alternatif, keputusan pembelian dan perilaku pasca pembelian. Data dalam penelitian dikumpulkan melalui instrumen penelitian berupa kuesioner sehingga diperlukan uji validitas dan reliabilitas agar kuesioner layak digunakan. Uji validitas bertujuan untuk memeriksa apakah kuesioner sebagai instrument penelitian sudah tepat untuk mengukur apa yang seharusnya diukur. Uji reliabilitas bertujuan untuk mencari tahu sampai sejauh mana alat ukur yang digunakan bersifat konsisten. Teknik analisis yang digunakan pada penelitian ini adalah analisis jalur (path analysis).

\section{HASIL DAN PEMBAHASAN}

Berdasarkan hasil penelitian, pengaruh langsung variabel e-service quality secara parsial terhadap variabel kepercayaan konsumen dan keputusan pengguna jasa serta pengaruh langsung variable kepercayaan konsumen secara parsial terhadap variabel keputusan pengguna jasa dapat dijelaskan sebagai berikut :

- Analisis Jalur $\mathrm{P}_{1}$ yaitu jalur $\mathrm{X}$ ke $\mathrm{Y}_{2}$ dengan nilai $\beta=0.453$ dan tingkat sign $=0,000$ (lebih kecil dari $0,05)$. Hasil tersebut dapat diartikan bahwa variabel $\mathrm{X}$ berpengaruh secara signifikan positif terhadap $\mathrm{Y}_{2}$ sebesar 0,453 , artinya setiap kenaikan satu point variabel $\mathrm{X}$ maka $\mathrm{Y}_{2}$ akan naik sebesar 0,453 ;

- Analisis Jalur $\mathrm{P}_{2}$ yaitu jalur $\mathrm{X}$ ke $\mathrm{Y}_{1}$ dengan tingkat $\beta=0,586$ dan tingkat sign $=0,019$ (lebih kecil dari 0,05). Hasil tersebut dapat diartikan bahwa variabel $\mathrm{X}$ berpengaruh secara signifikan positif terhadap $\mathrm{Y}_{1}$ sebesar 0,568 , artinya setiap kenaikan satu point variabel $\mathrm{X}$ maka $\mathrm{Y}_{1}$ akan naik sebesar 0,568 ;

- Analisis Jalur $P_{3}$ yaitu jalur $Y_{1}$ ke $Y_{2}$ dengan tingkat $\beta=0,665$ dan tingkat sign $=0,008$ (lebih kecil dari 0,05). Hasil tersebut dapat diartikan bahwa variabel $\mathrm{Y}_{1}$ berpengaruh secara signifikan positif terhadap $\mathrm{Y}_{2}$ sebesar 0,665, artinya setiap kenaikan satu point variabel $\mathrm{Y}_{1}$ maka $\mathrm{Y}_{2}$ akan naik sebesar 0,665

Berdasarkan penjelasan di atas, maka pengaruh langsung dari variabel yang diukur dalam penelitian ini dapat dilihat pada gambar 1 diatas, maka dapat dihitung pengaruh tidak langsung e-service quality $(\mathrm{X})$ terhadap keputusan pengguna jasa $\left(\mathrm{Y}_{2}\right)$ melalui kepercayaan konsumen $\left(\mathrm{Y}_{1}\right)$ untuk mencari pengaruh tidak langsung adalah sebagai berikut:

PTL $\left(X-Y_{2}\right)=\mathrm{P}_{2} \times \mathrm{P}_{3}$

Keterangan : PTL $\left(X-Y_{2}\right)=$ Pengaruh tidak langsung variable $X$ terhadap variable $Y_{2} ; P_{2}=$ Pengaruh langsung variable $\mathrm{X}$ terhadap $\mathrm{Y}_{1} ; \mathrm{P}_{3}=$ Pengaruh $\mathrm{Y}_{1}$ terhadap $\mathrm{Y}_{2}$

Maka dengan rumus tersebut diatas dapat dilakukan perhitungan sebagai berikut :

PTL $\left(X-Y_{2}\right)=0,586 \times 0,665=0,390$ 
Analisis regresi dengan variabel mediasi digunakan untuk mengetahui total pengaruh variabel independent terhadap variabel dependen yang terdiri dari pengaruh langsung dan pengaruh tidak langsung, yakni melalui variabel mediasi dengan menggunakan rumus sebagai berikut

$\mathrm{TP}=\mathrm{P}_{1}+\left(\mathrm{P}_{2} \times \mathrm{P}_{3}\right)$

Keterangan : TP $=$ Total Pengaruh; $\mathrm{P}_{1}=$ Pengaruh langsung variable $\mathrm{X}$ terhadap $\mathrm{Y}_{2} ; \mathrm{P}_{2}=$ Pengaruh langsung variable $\mathrm{X}$ terhadap $\mathrm{Y}_{1} ; \mathrm{P}_{3}=$ Pengaruh $\mathrm{Y}_{1}$ terhadap $\mathrm{Y}_{2}$

Maka dengan rumus tersebut diatas dapat dilakukan perhitungan sebagai berikut

$\mathrm{TP}=0,453+(0,586 \times 0,665)=0,453+0,390=0,843$

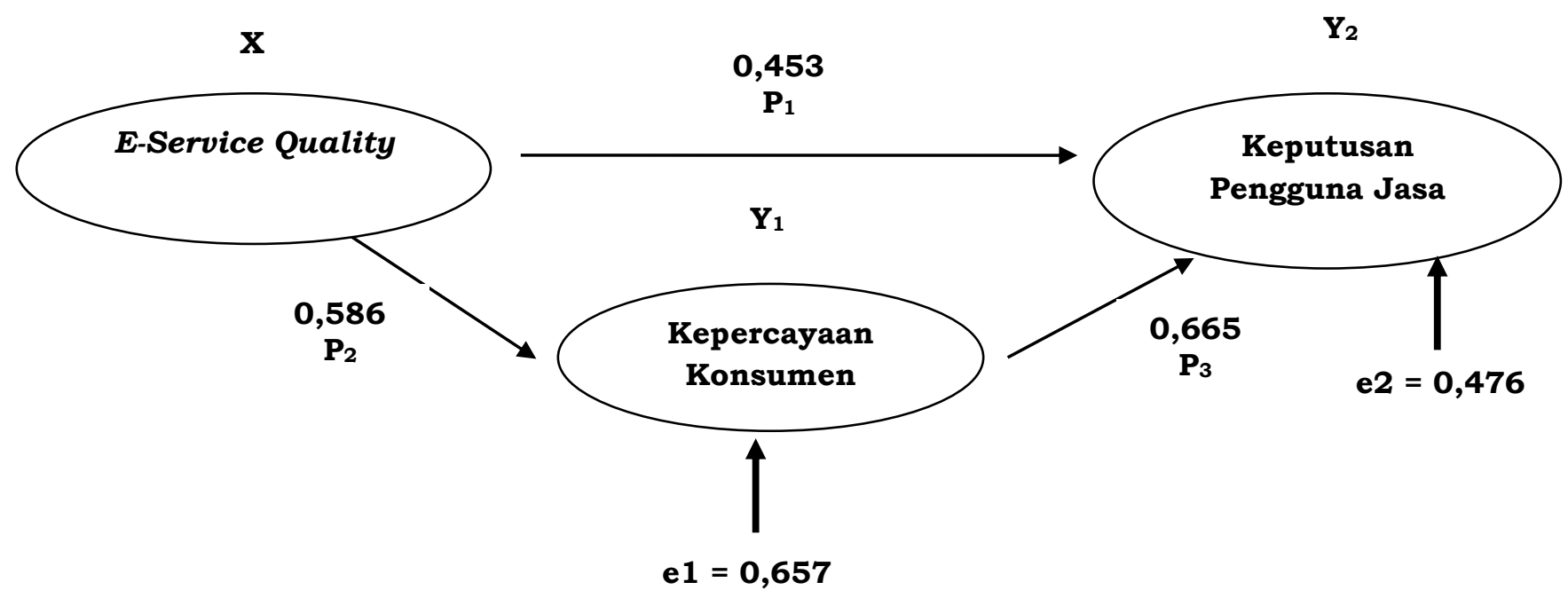

\section{Gambar 1 \\ Model Lintasan Pengaruh}

Berdasarkan hasil perhitungan diatas maka hasil pengaruh langusng, pengaruh tidak langsung dan pengaruh total antar variabel dapat lihat sebagai berikut :

Tabel 1

Total Pengaruh Langsung dan Pengaruh tidak Langsung Antar Variabel

\begin{tabular}{lrrr}
\hline Pengaruh Variabel & Pengaruh Langsung & Pengaruh tak langsung via mediasi & \multicolumn{2}{c}{ Pengaruh Total } \\
\hline $\mathrm{X} \rightarrow \mathrm{Y}_{2}$ & 0,453 & 0,390 & 0,843 \\
$\mathrm{X} \rightarrow \mathrm{Y}_{1}$ & 0,586 & & 0,586 \\
$\mathrm{Y}_{1} \rightarrow \mathrm{Y}_{2}$ & 0,665 & & 0,665 \\
\hline
\end{tabular}

Sumber: data olahan

Tabel 1 diatas, terlihat hasil perhitungan pengaruh langsung dan pengaruh tidak langsung melalui mediasi, apabila nilai total pengaruh lebih besar dari pada pengaruh langsung (TP $>\mathrm{P}_{1}$ ) berarti variabel tersebut marupakan variabel mediasi. Dari perhitungan diatas Total Pengaruh (TP) sebesar 0,843 lebih besar dari pada Pengaruh Langsung $\left(\mathrm{P}_{1}\right)$ sebesar 0,453 maka variabel tersebut dapat dikatakan sebagai variabel mediasi. Keragaman data yang dapat dijelaskan oleh model Analisis Path tersebut sebesar 0.843 atau 84,3\% atau dengan kata lain informasi yang terkandung dalam data $84,3 \%$ dapat dijelaskan oleh model tersebut.

\section{E-service Quality terhadap Kepercayaa Konsumen}

Hasil analisis data tanggapan yang disampaikan responden memperlihatkan bahwa e-service quality berpengaruh signifikan terhadap kepercayaan konsumen pengguna jasa ojek online Go-Ride pada aplikasi Go-Jek di Kota Jambi. Besarnya pengaruh e-service quality terhadap kepercayaan konsumen adalah sebesar 0,577 dan signifikansi $0.019<0,05$. Angka tersebut membuktikan bahwa secara parsial variabel independen e-service quality menyangkut ease of use, website design, responsiveness dan assurance berpengaruh 
terhadap kepercayaan konsumen, dimana terdapat pengaruh positif yang dapat diartikan bahwa semakin baik e-service quality maka semakin meningkat kepercayaan konsumen pengguna jasa ojek online Go-Ride pada aplikasi Go-Jek di Kota Jambi. Kepercayaan merupakan sesuatu yang timbul ketika salah satu kelompok yakin atau percaya dengan reabilitas atau keandalan dan integritas. Faktor-faktor yang terdapat dalam indikator dari penelitian merupakan kemudahan konsumen dalam menggunakan aplikasi Go-Jek, ketertarikan terhadap design aplikasi Go-Jek dan respon yang cepat pada pemesanan ojek online melalui aplikasi Go-Jek serta jaminan keamaan untuk bertransaksi aplikasi maupun jasa ojek pada Go-Jek. Disamping itu, informasi yang lengkap dan mudah dimengerti dapat menumbuhkan rasa kepercayaan konsumen dalam menggunakan layanan. Fitur pada aplikasi Go-Jek menumbukan rasa kepercayaan konsumen saat menggunakannya, hal ini dapat dikatakan bahwa reputasi, keamaan bertransaksi dan keandalan dari aplikasi Go-Jek telah akui oleh konsumen yang menggunakannya.

\section{E-service Quality dan Kepercayaan Konsumen terhadap Keputusan Pengguna Jasa}

Hasil analisis data tanggapan yang disampaikan responden memperlihatkan bahwa e-service quality berpengaruh signifikan terhadap keputusan pengguna jasa ojek online Go-Ride pada aplikasi Go-Jek di Kota Jambi. Besarnya pengaruh e-service quality terhadap keputusan pengguna jasa adalah sebesar 0,427 dengan signifikansi $0,000<0,05$. Angka tersebut membuktikan bahwa secara parsial variabel independen $e$-service quality menyangkut ease of use, website design, responsiveness dan assurance berpengaruh terhadap keputusan pengguna jasa. Dari hasil tersebut terdapat pengaruh positif yang dapat diartikan bahwa semakin baik e-service quality maka keputusan pengguna jasa ojek online Go-Ride pada aplikasi Go-Jek di Kota Jambi akan semakin meningkat.

Niat pelanggan untuk mengadopsi teknologi informasi yang baru ditentukan oleh kemudahan pengguna serta kegunaan dari teknologi tersebut. Kemudahan konsumen dalam menggunakan aplikasi GoJek, ketertarikan terhadap design aplikasi Go-Jek dan respon yang cepat pada pemesanan ojek online melalui aplikasi Go-Jek serta jaminan keamaan bertransaksi pada aplikasi maupun jasa ojek pada Go-Jek mempengaruhi konsumen dalam mengambil keputusan menggunakan jasa ojek online Go-Ride. Konsumen dalam menggunakan jasa ojek sangat ingin mendapatkan pelayanan yang praktis, aman dan fungsi layanan yang lengkap, hal ini telah ditunjukan oleh pelayanan dari Go-Jek dalam melakukan pelayanan jasa. Disamping itu, hasil analisis data tanggapan yang disampaikan responden memperlihatkan bahwa kepercayaan konsumen berpengaruh signifikan terhadap keputusan pengguna jasa ojek online Go-Ride pada aplikasi Go-Jek di Kota Jambi. Besarnya pengaruh kepercayaan konsumen terhadap keputusan pengguna jasa adalah sebesar 0,641 dengan signifikansi 0,008 < 0,05. Angka tersebut membuktikan bahwa secara parsial variabel independen kepercayaan konsumen menyangkut reputasi, keamanan dan keandalan sistem berpengaruh terhadap keputusan pengguna jasa. Dari hasil tersebut terdapat pengaruh positif yang dapat diartikan bahwa semakin meningkat kepercayaan konsumen maka keputusan pengguna jasa ojek online GoRide pada aplikasi Go-Jek di Kota Jambi akan semakin meningkat

Menurut Kasim \& Abdullah (2010) bahwa ketika kepercayaan dikonseptualisasikan sebagai dimensi dari model penerimaan teknologi maka kepercayaan dapat memiliki pengaruh terhadap kesediaan konsumen dalam bertransaksi. Reputasi pelayanan Go-Jek, keamanan dalam bertansaksi dan menggunakan jasa ojek pada Go-Jek serta keandalan sistem dari aplikasi Go-Jek membuat kepercayaan konsumen pengguna jasa ojek online Go-Ride semakin meningkat. Mengidentifikasi kepercayaan sebagai elemen psikologis yang menyatukan dua konsep kepercayaan kognitif dan afektif. Seseorang individu memeliki kepercayaan kognitif ketika ia memiliki faktor-faktor yang masuk akal dalam objek kepercayaan atau ketika ia dipengaruhi oleh perasaan positif yang kuat terhadap kepercayaan. Hasil penelitian menggambarkan bahwa pelayanan yang diberikan oleh Go-Jek dalam jasa ojek online telah mempengaruhi perasaan positif yang kuat terhadap konsumen sehingga tumbuh rasa kepercayaan dalam memutuskan untuk menggunakan jasa ojek online pada Go-Jek

\section{E-service Quality terhadap Keputusan Pengguna Jasa melalui Kepercayaan Konsumen}

Hasil analisa data tanggapan yang disampaikan responden pada pengaruh langsung memperlihatkan bahwa terdapat pengaruh e-service quality terhadap keputusan pengguna jasa ojek online Go-Ride pada 
aplikasi Go-Jek di Kota Jambi.sebesar 0,427 dengan signifikansi 0,000 <0,05. Selain itu hasil analisa data tanggapan responden pada pengaruh tidak langsung memperlihatkan bahwa pengaruh e-service quality terhadap keputusan pengguna jasa ojek online Go-Ride pada aplikasi Go-Jek melalui kepercayaan konsumen di Kota Jambi sebesar 0,390 sehingga dengan analisis regresi melalui intervening diperoleh total dari pengaruh langsung dan pengaruh tidak langsung sebesar 0,843 . Hal ini dapat diartikan bahwa jika total pengaruh lebih besar dari pada pengaruh langsung maka variabel kepercayaan dikatakan sebagai variabel mediasi. Keragaman data yang dapat dijelaskan oleh model Analisis Path tersebut sebesar 0.843 atau 84,3\% atau dengan kata lain informasi yang terkandung dalam data 84,3\% dapat dijelaskan oleh model tersebut.

Menurut Winardi (2010), keputusan pembelian atau menggunakan jasa merupakan titik suatu pembelian atau pengguna jasa dari proses evaluasi, sedangkan menurut Kotler dan Keller (2009) proses keputusan pembelian konsumen atau menggunakan jasa harus melewati lima tahap yaitu pengenalan masalah, pencarian informasi, evaluasi alternatif, keputusan pembelian dan perilaku pasca pembelian. Konsumen mengalami proses evaluasi dalam memutuskan untuk menggunakan jasa ojek online pada Go-Jek dengan melihat faktor dalam e-service quality, yaitu kemudahan konsumen dalam menggunakan aplikasi Go-Jek, ketertarikan terhadap design aplikasi Go-Jek dan respon yang cepat pada pemesanan ojek online melalui aplikasi Go-Jek serta jaminan keamanan bertransaksi pada aplikasi maupun jasa ojek pada Go-Jek, semakin baik e-service quality maka hasil dari proses evaluasi tersebut akan semakin baik dalam memutuskan untuk menggunakan jasa ojek online pada Go-Jek. Disamping itu faktor yang memperkuat konsumen dalam memutuskan untuk menggunakan jasa ojek online yaitu menumbukan kepercayaan konsumen, dimana faktor-faktor dalam menumbuhkan dan meningkatkan kepercayaan konsumen adalah reputasi pelayanan Go-Jek, kemanan dalam bertransaksi dan menggunakan jasa ojek pada Go-Jek serta keandalan sistem dari aplikasi Go-Jek. E-service quality dapat mempengaruhi seseorang dalam memutuskan pengguna jasa ojek online pada Go-Jek, tetapi dengan adanya kepercayaan konsumen sebagai mediasi dapat memperkuat pengaruh e-service quality terhadap seseorang dalam memutuskan untuk menggunakan jasa ojek online Go-Ride pada aplikasi Go-Jek.

\section{KESIMPULAN}

Berdasarkan analisis terbukti bahwa e-service quality memberikan pengaruh yang signifikan terhadap kepercayaan konsumen pengguna jasa ojek online Go-Ride pada aplikasi Go-Jek di Kota Jambi. Berdasarkan analisis terbukti bahwa e-service quality dan kepercayaan konsumen memberikan pengaruh yang signifikan terhadap keputusan pengguna jasa ojek online Go-Ride pada aplikasi Go-Jek di Kota Jambi. Berdasarkan analisis terbukti bahwa e-service quality memberikan pengaruh yang signifikan terhadap keputusan pengguna jasa ojek online Go-Ride pada aplikasi Go-Jek melalui kepercayaan konsumen di Kota Jambi

\section{DAFTAR PUSTAKA}

Adisetiawan, R., 2013, Kajian Persepsi Pemilik Usaha Kecil dan Menengah (UKM) Terhadap Laporan Keuangan, Jurnal Ilmiah Universitas Batanghari Jambi, 13(4), 162-173

Asmas., Denny, Hasminidiarty, dan Adisetiawan, R., 2018, Struktur Modal dan Variabel yang Mempengaruhinya, JMAS (Jurnal Manajemen dan Sains), 3(2), 237-250

Kotler, P dan Kevin Lane Keller. 2009. Manajemen Pemasaran, Edisi Ketiga Belas Judul 1. Jakarta : Erlangga

Norizan Kassim, Mor Asiah Abdullah. 2010. The Effect of perceived service quality deminsions on customer satisfaction, trust and loyality in e-commerce settings : A cross cultural analysis, Asia Pacific Journal of Marketing and Logistic, 22(3), 351-371

Rowley, J. 2006. An Analysis of the E-service Literature. Toward a Research Agenda. Internet Research, 16(3), 339-359

Winardi. 2010. Kepemimpinan dan Manajemen. Jakarta : PT. Rineka Cipta 